\title{
Optimization of the ultrasonic treatment for improving catalytic activity of glucoamylase preparation
}

- Tran Thi Thu Tra

- Le Van Viet Man

Department of Food Technology, Ho Chi Minh city University of Technology, VNU-HCM

(Manuscript Received on March 12 ${ }^{\text {nd }}, 2015$, Manuscript Revised September 04 ${ }^{\text {nd }}, 2015$ )

\begin{abstract}
In this work, ultrasonic treatment was $\pm 0.213 \mathrm{KU} / \mathrm{mL}$ and this value increased 11 used for improving the catalytic activity of glucoamylase preparation Dextrozyme GA. The ultrasonic temperature, power and time were optimized by a Central Composite Circumscribed design for maximizing of the catalytic activity of the preparation. The optimal ultrasonic temperature, power and time were $30^{\circ} \mathrm{C}, 20 \mathrm{~W} / \mathrm{mL}$ and $33 \mathrm{sec}$, respectively. Under these conditions, the $\%$ in comparison with that in the control without ultrasonic treatment. Our results also showed that $V_{\max }$ and $K_{M}$ of the sonicated Dextrozyme GA preparation were higher than those of the control. The ultrasonic treatment would be a potential method for improving the catalytic activity of the glucoamylase preparation in starch hydrolysis.
\end{abstract} maximum glucoamylase activity was 83.142

Keyword: glucoamylase, optimization, ultrasonic treatment,

\section{INTRODUCTION}

In food industry, ultrasonic treatment can be considered as a potential method for enzyme inactivation. Ultrasound generated cavitation that could cause the change in protein structure and reduce enzyme activity [1]. Under mild treatment conditions, however, ultrasound could increase enzyme activity. This phenomenon was observed for different enzymes including amylase [2], [3], cellulase [4], dextranase [5], pectinase [6]... It was explained that slight modification of protein conformation facilitated the formation of enzyme-substrate complex and that resulted in an improved catalytic activity of the sonicated enzyme preparation [1].

Recently, our study showed that the ultrasonic treatment of glucoamylase preparation Dextrozyme GA under certain circumstance could improve the enzyme activity [7]. Nevertheless, optimal sonication conditions 
for maximizing catalytic activity of enzyme preparations have never been reported.

The objective of this study was to optimize the sonication conditions for maximizing glucoamylase activity of the preparation as well as to compare kinetic parameters of the sonicated and unsonicated glucoamylase preparations.

\section{MATERIALS AND METHODS}

\subsection{Materials}

Dextrozyme GA produced from a genetically modified strain of an Aspergillus $s p$. with an activity of 270 amyloglucosidase units per gram was purchased from Novozymes, Denmark. The maltodextrin with dextrose equivalent (DE) of 20 used as substrate, 3,5dinitrosalicylic acid and citrate phosphate buffer were purchased from Merck - Schuchardt OHG and KGaA (Germany).

\subsection{Experimental methods}

Samples of $15 \mathrm{~mL}$ enzyme preparation were taken in $50 \mathrm{~mL}$ beakers and sonicated with a horn type ultrasonic probe (Sonic Vibra-Cell VC 750, The United States) at the frequency of
$20 \mathrm{kHz}$. During the sonication, the beakers were placed in a thermostatic water bath (Memmert, Germany) for temperature regulation. At the end of the treatment, the amylase activity of the sonicated and unsonicated samples was determined.

\subsubsection{Optimization of ultrasonic treatment} for improving the catalytic activity of the glucoamylase preparation

Our preliminary study showed that the catalytic activity of Dextrozyme GA was strongly improved when the ultrasonic temperature, power and time were $30^{\circ} \mathrm{C}$, $20 \mathrm{~W} / \mathrm{mL}$ and 30 s, respectively. These values were therefore selected as central conditions for optimization experiment.

Ultrasonic treatment of Dextrozyme GA preparation was optimized by Central Composite Circumscribed design with 3 variables and 5 levels (Table 1). The dependant variable was amylase activity $(\mathrm{KU} / \mathrm{mL})$. The software Modde (version 5.0) was used to generate the experimental planning and to process data. The experiment included 20 points (Table 2).

Table 1. Independent variables and their levels in the response surface design

\begin{tabular}{|l|c|c|c|c|c|}
\hline \multirow{2}{*}{\begin{tabular}{c}
\multirow{2}{*}{ Independent variables } \\
\cline { 2 - 6 }
\end{tabular}} & $-2^{3 / 4}$ & -1 & 0 & +1 & $+2^{3 / 4}$ \\
\cline { 2 - 6 } $\mathrm{X}_{1}-$ Ultrasonic temperature $\left(\mathrm{T}-{ }^{\circ} \mathrm{C}\right)$ & 13 & 20 & 30 & 40 & 47 \\
\hline $\mathrm{X}_{2}-$ Ultrasonic power $(\mathrm{P}-\mathrm{W} / \mathrm{mL})$ & 12 & 15 & 20 & 25 & 28 \\
\hline $\mathrm{X}_{3}-$ Ultrasonic time $(\mathrm{t}-\mathrm{sec})$ & 5 & 15 & 30 & 45 & 55 \\
\hline
\end{tabular}

The second order polynomial equation was as follow:

$$
Y_{\text {coded }}=b_{0}-b_{1} X_{1}+b_{2} X_{2}+b_{\mathrm{g}} X_{\mathrm{g}}+b_{11} X_{1}^{2}+b_{22} X_{2}^{2}+b_{\mathrm{gB}} X_{\mathrm{B}}^{2}+b_{12} 1 X_{1} X_{2}+b_{1 \mathrm{~g}} X_{1} X_{\mathrm{B}}+b_{2 \mathrm{~B}} X_{2} X_{\mathrm{g}}
$$


Where $Y_{\text {coded }}$ was the response variable (amylase activity), $X$ were the coded independent variables (Table 1), and $b$ were the regression coefficients.

The analysis of variance was conducted, the effect and regression coefficients of individual linear, quadratic and interaction terms were determined. The significance of each coefficient in the equation was tested using the Student t-test. The regression coefficients were used for statistical calculations to generate the response variable.

\subsubsection{Comparison of kinetic parameters of} the sonicated and unsonicated glucoamylase preparations

In this experiment, the ultrasonic temperature, power and time were selected from the results of section 2.2.1. The sonicated and unsonicated enzyme preparations in phosphate buffer were used. Kinetic parameters $\mathrm{Km}$ and Vmax of the sonicated and unsonicated enzyme preparations were determined by LineweaverBurk method using various maltodextrin concentration $(0.05-0.20 \% \quad \mathrm{w} / \mathrm{v})$. The experiment was carried out at $65^{\circ} \mathrm{C}$ and $\mathrm{pH} 4.0$.

\subsection{Analytical methods}

Amylase activity was assayed by the modified method of Bernfeld (1955). 0.5mL of $0.4 \%(\mathrm{w} / \mathrm{v})$ maltodextrin solution was mixed with $0.5 \mathrm{~mL}$ of citrate phosphate buffer $(\mathrm{pH} 4.0)$ and $0.1 \mathrm{~mL}$ of the enzyme solution (The dilution factor for the enzyme preparation was 10000 times) [8]. The mixture was incubated at $65^{\circ} \mathrm{C}$ for $5 \mathrm{~min}$. The reaction was stopped with $1 \mathrm{~mL}$ of 3,5-dinitrosalicylate reagent. The mixture was then kept in boiling water for $5 \mathrm{~min}$, cooled to the ambient temperature and measured for absorbance at 540nm using UV-visible spectrophotometer (Genesys 6, The United States). One unit (U) of glucoamylase preparation was defined as the amount the enzyme that liberates $1 \mu \mathrm{mol}$ of reducing sugar as glucose in $1 \mathrm{~mL}$ for $1 \mathrm{~min}$ under the assay conditions.

\subsection{Statistical analysis}

All experiments were performed in triplicate. The experimental results were expressed as means \pm SD. The data was analyzed for statistical significance by Analysis of Variance (ANOVA). Multiple Range Test with the Least Significant Difference $\left(\mathrm{LSD}_{0.05}\right)$ was applied in order to determine which means are significantly different from which others by using STATGRAPHICS (C) Plus for windows 3.0 .

\section{RESULTS AND DISCUSSION}

3.1. Optimization of the ultrasonic treatment for improve amylase activity of glucoamylase preparation

Table 2 presents the amylase activity in function of ultrasonic temperature, power and time. The estimated effects of the independent variables on amylase activity are shown in Table 3. All the quadratic and cross-product coefficients were significant $(\mathrm{P}<0.05)$. One linear coefficient was eliminated in the refined equation as its effect was not significant. Neglecting the insignificant term, the regression equation for coded values and actual experimental values were given as Equation (2) and Equation (3), respectively.

Table 4 presents ANOVA of the fitted model. According to the ANOVA table, the regression model is significant at the considered confidence level since a satisfactory correlation 
coefficient was obtained and the F-value was 15 times more than the F listed value.

$Y_{\text {coded }}=83.260-0.161 X_{2}+0.248 X_{2}-0.723 X_{1}^{2}-0.918 X_{2}^{2}-0.688 X_{3}^{2}-0.263 X_{1} X_{2}+0.262 X_{1} X_{3}-0.263 X_{2} X_{3}$

$Y_{\text {actual }}=34.695+1.841 P+1.856 t-0.029 T^{2}-0.037 P^{2}-0.003 t^{2}-0.011 P T+0.003 T \cdot t-0.004 P t$

Table 2. Experimental planning and results of amylase activity for ultrasonic treatment

\begin{tabular}{|c|c|c|c|c|}
\hline Run & $\mathrm{X}_{1}$ & $\mathrm{X}_{2}$ & $X_{3}$ & Amylase activity (KU/mL) \\
\hline 1 & -1 & -1 & -1 & $80.626 \pm 0.106$ \\
\hline 2 & 1 & -1 & -1 & $80.871 \pm 0.184$ \\
\hline 3 & -1 & 1 & -1 & $81.301 \pm 0.106$ \\
\hline 4 & 1 & 1 & -1 & $80.442 \pm 0.106$ \\
\hline 5 & -1 & -1 & 1 & $81.117 \pm 0.106$ \\
\hline 6 & 1 & -1 & 1 & $82.344 \pm 0.184$ \\
\hline 7 & -1 & 1 & 1 & $80.565 \pm 0.106$ \\
\hline 8 & 1 & 1 & 1 & $80.933 \pm 0.106$ \\
\hline 9 & -1.682 & 0 & 0 & $81.178 \pm 0.106$ \\
\hline 10 & 1.682 & 0 & 0 & $80.994 \pm 0.213$ \\
\hline 11 & 0 & -1.682 & 0 & $80.749 \pm 0.213$ \\
\hline 12 & 0 & 1.682 & 0 & $80.380 \pm 0.213$ \\
\hline 13 & 0 & 0 & -1.682 & $80.749 \pm 0.281$ \\
\hline 14 & 0 & 0 & 1.682 & $81.669 \pm 0.213$ \\
\hline 15 & 0 & 0 & 0 & $83.203 \pm 0.281$ \\
\hline 16 & 0 & 0 & 0 & $83.449 \pm 0.184$ \\
\hline 17 & 0 & 0 & 0 & $83.326 \pm 0.281$ \\
\hline 18 & 0 & 0 & 0 & $83.224 \pm 0.221$ \\
\hline 19 & 0 & 0 & 0 & $83.414 \pm 0.191$ \\
\hline 20 & 0 & 0 & 0 & $83.117 \pm 0.231$ \\
\hline
\end{tabular}


Table 3. Estimated effects of independent variables on amylase activity of the ultrasonic samples

\begin{tabular}{|c|c|c|c|c|}
\hline Factor & Coefficient estimate of coded factors & Std. Err. & t- value & P- value \\
\hline$X_{0}$ & 83.260 & 0.080 & 1575.76 & $1.7 .10^{-26}$ \\
\hline$X_{1}$ & 0.041 & 0.053 & 1.40 & $0.37^{*}$ \\
\hline$X_{2}$ & -0.161 & 0.053 & 4.89 & $0.9 .10^{-3}$ \\
\hline$X_{3}$ & 0.248 & 0.053 & 6.83 & $0.1 .10^{-3}$ \\
\hline$X_{11}$ & -0.723 & 0.052 & 20.92 & $6.1 .10^{-8}$ \\
\hline$X_{22}$ & -0.918 & 0.052 & 26.33 & $7.1 .10^{-9}$ \\
\hline$X_{33}$ & -0.688 & 0.052 & 19.65 & $1.1 .10^{-7}$ \\
\hline$X_{1} X_{2}$ & -0.263 & 0.070 & 5.36 & $0.5 .10^{-3}$ \\
\hline$X_{1} X_{3}$ & 0.262 & 0.070 & 6.03 & $0.3 .10^{-3}$ \\
\hline$X_{2} X_{3}$ & -0.263 & 0.070 & 6.03 & $0.3 .10^{-3}$ \\
\hline
\end{tabular}

* Non significant variables

Table 4. Analysis of variance of the regression model in experiments of sonication treatment

\begin{tabular}{|c|c|c|c|c|c|}
\hline Source of variation & Degree of freedom & Sum of squares & Mean square & F-value & p-value \\
\hline Regression & 9 & 25.39 & 2.82 & 72.71 & 0.00 \\
\hline Residual & 10 & 0.39 & 0.04 & & \\
\hline Total Corrected & 19 & 25.78 & 1.35 & & \\
\hline F listed value & \multicolumn{2}{|c|}{0.314} & 0.06 & 3.63 & 0.092 \\
\hline Lack of Fit & 5 & 0.37 .88 & \\
\hline
\end{tabular}

Surface response graph, obtained by using the fitted model presented in Eq. (3), is presented in Fig. 2. The interaction of ultrasonic temperature and power, ultrasonic power and time, ultrasonic temperature and time on the catalytic activity of the glucoamylase preparation were described by parabolic shape. These interactions have never been reported not only for glucoamylase preparation but also for other enzyme preparations.
Based on the developed model (equation (3)) for ultrasonic treatment, the optimum conditions for improving amylase activity were determined using Modde 5.0 software. The model predicted that as the ultrasonic temperature, power and time are $30^{\circ} \mathrm{C}, 19.3 \mathrm{~W} / \mathrm{mL}$ and $33 \mathrm{sec}$, respectively, the catalytic activity of glucoamylase preparation would achieve the maximum of $83.300 \mathrm{KU} / \mathrm{mL}$. 

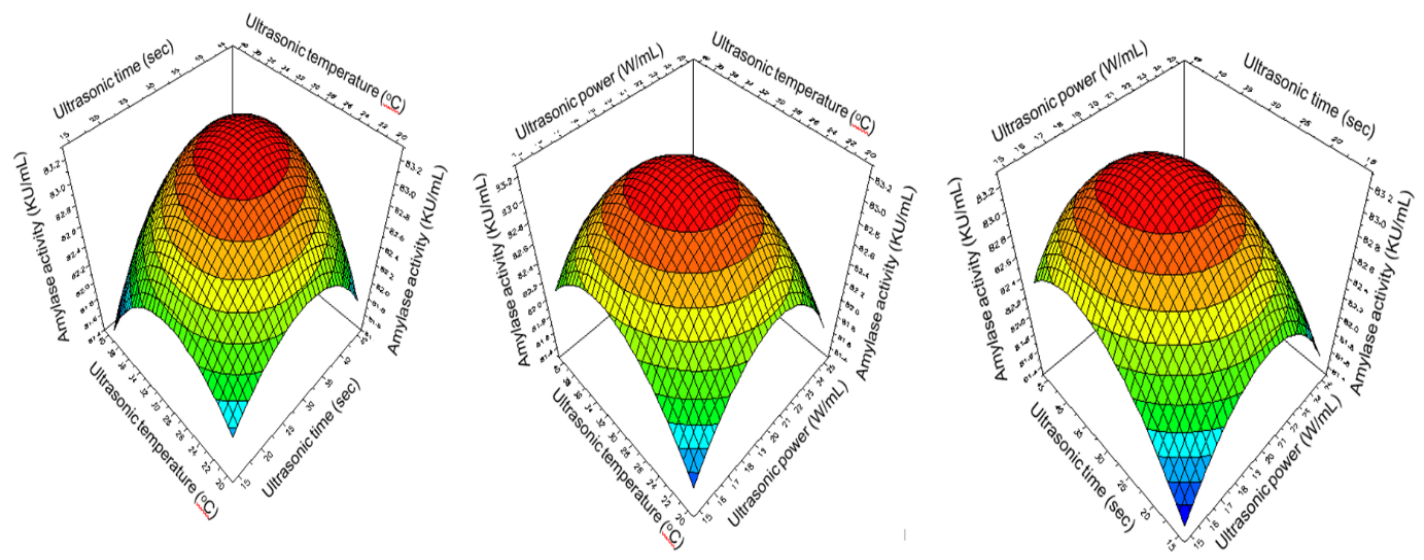

Figure 1. Fitted surface for amylase activity of ultrasonic treatment of glucoamylase as a function of ultrasonic temperature, power and time.

In order to verify the accuracy of the model, three independent replicates were carried out for measuring amylase activity under the optimal conditions: ultrasonic temperature of $30^{\circ} \mathrm{C}$, power of $20 \mathrm{~W} / \mathrm{mL}$ and time of $33 \mathrm{sec}$. The experimentation shows that the amylase activity was $83.142 \pm 0.213 \mathrm{KU} / \mathrm{mL}$. The experimental value was therefore nearly similar to the theoretical value $(83.300 \mathrm{KU} / \mathrm{mL})$ from the model. Simultaneously, the catalytic activity of the unsonicated glucoamylase preparation was also tested as control. The amylase activity of the control was $74.857 \pm 0.106 \mathrm{KU} / \mathrm{mL}$. Thus, sonication increased catalytic activity of the glucoamylase preparation by $11 \%$ in comparison with the control without ultrasonic treatment.

\subsection{Comparison of catalytic characteristics of the sonicated and unsonicated enzyme preparations}

$\mathrm{V}_{\max }$ and $\mathrm{K}_{\mathrm{m}}$ of the sonicated and unsonicated glucoamylase preparations are presented in Table 5.
Table 5. Kinetic parameters of the sonicated and unsonicated glucoamylase preparations

\begin{tabular}{|l|l|c|}
\hline \multicolumn{1}{|c|}{ Sample } & \multicolumn{1}{|c|}{$\begin{array}{c}\mathrm{V}_{\max } \\
(\mu \mathrm{M} / \mathrm{min})\end{array}$} & $\begin{array}{c}\mathrm{K}_{\mathrm{m}} \\
(\mu \mathrm{M})\end{array}$ \\
\hline $\begin{array}{l}\text { Ultrasonic } \\
\text { treatment }\end{array}$ & $517 \pm 1$ & $0.154 \pm 0.001$ \\
\hline Control & $413 \pm 2$ & $0.141 \pm 0.002$ \\
\hline \multicolumn{1}{|c|}{ Sonication increased } & $\mathrm{V}_{\max }$ of the
\end{tabular}
glucoamylase preparation. The obtained results in section 3.1 showed that ultrasonic treatment improved the amylase activity and that resulted in higher $\mathrm{V}_{\max }$. However, sonication also augmented $\mathrm{K}_{\mathrm{m}}$ of the glucoamylase preparation. High $\mathrm{K}_{\mathrm{m}}$ indicates that $\mathrm{V}_{\max }$ will only be reached if the substrate concentration is high enough to saturate the enzyme [9]. It should be noted that high substrate concentration would improve economic efficiency in starch hydrolysis [9]. Similar increase in both $\mathrm{V}_{\max }$ and $\mathrm{K}_{\mathrm{m}}$ value was recently reported by Bashari et al. (2013) who 
compared kinetic parameters of sonicated and unsonicated dextrinase preparation [5].

\section{CONCLUSIONS}

Ultrasonic technology was performed for improvement in catalytic activity of glucoamylase preparation. A central composite circumscribed design was used to estimate and optimize the experimental variables: ultrasonic temperature, power and time. The optimal of ultrasonic conditions were determined as follows: ultrasonic temperature of $30^{\circ} \mathrm{C}$, ultrasonic power of $20 \mathrm{~W} / \mathrm{mL}$ and ultrasonic time of 33 sec. Under these conditions, the glucoamylase activity was $83.142 \pm 0.213$ $\mathrm{KU} / \mathrm{mL}$ and this value increased $11 \%$ in comparison with that in the control without ultrasonic treatment. In addition, sonication increased enzyme kinetic parameters including $\mathrm{V}_{\max }$ and $\mathrm{K}_{\mathrm{m}}$. Increase in enzyme activity of commercial preparations is an important benefit for industrial application. Further research needs to be conducted to clarify the impact of ultrasound on enzyme structure and catalytic activity.

\section{Tối ưu hóa quá trình xử lý siêu âm để làm tăng hoạt tính xúc tác của chế phẩm glucoamylase}

\section{- Trần Thị Thu Trà}

- Lê Văn Việt Mẫn

Bộ môn Công nghệ Thực Phẩm, Trường Đại học Bách khoa, ĐHQG-HCM

\section{TÓM TẮT}

Trong nghiên cứu này, quá trình xử lý siêu âm được sử dụng để làm tăng hoạt tính xúc tác của chế phẩm glucoamylase Dextrozyme GA. Nhiệt độ, công suất và thời gian siêu âm được tối ưu hóa bằng phương pháp quy hoạch thực nghiệm theo phương pháp quay bậc hai của Box và Hunter, cấu trúc có tâm để hoạt tính xúc tác của chế phẩm glucoamylase đạt cực đại. Giá trị nhiệt độ, công suất và thời gian siêu âm tối ưu lần lượt là $30^{\circ} \mathrm{C}, 20 \mathrm{~W} / \mathrm{mL}$ và 33 giây.
Khi đó, hoạt tính glucoamylase cao nhất là $83.142 \pm 0.213 \mathrm{KU} / \mathrm{mL}$ và giá trị này cao hơn $11 \%$ so với mẫu đối chứng không qua xử lý siêu âm. Kết quả nghiên cứu cũng cho thấy các giá trị $K_{m}$ và $V_{\max }$ của chế phẩm enzyme đã qua xử lý siêu âm đều cao hơn so với mẫu đối chứng. Xử lý siêu âm có thể được xem là một giải pháp tiềm năng để làm tăng hoạt tính xúc tác của chế phẩm glucoamylase trong quá trình thủy phân tinh bột.

Từ khóa: glucoamylase, tối ưu hóa, xử lý siêu âm. 


\section{REFERENCES}

[1]. R. Mawson, M. T. N. Gamage and K. Knoerzer, "Ultrasound in enzyme activation and inactivation," in Ultrasound Technologies for Food and Bioprocessing, Springer, 2010, pp. 369-404 .

[2]. M. Souza, E. Mezadri, E. Zimmerm, E. Leaes, M. Bassaco, V. Prá, E. Foletto, A. Cancellier, L. M. Terra, S. Jahn and M. Mazutt, "Evaluation of activity of a commercial amylase under ultrasoundassisted irradiation," Ultrasonics Sonochemistry, vol. 20, no. 1, p. 89-94, January 2013.

[3]. E. X. Leaes, D. Lima, L. Miklasevicius, A. Ramon, V. Prá, M. Bass, L. Terra and M. Mazutti, "Effect of ultrasound-assisted irradiation on the activities of $\alpha$-amylase and amyloglucosidase," Biocatalysis and Agricultural Biotechnology, vol. 2, p. 2125, 23 August 2013.

[4]. Z. Wang, X. Lin, P. Li, J. Zhang, S. Wang and H. Ma, "Effects of low intensity ultrasound on cellulase pretreatment,"
Effects of low intensity ultrasound on cellulase pretreatment, vol. 117, p. 222 227, 2012.

[5]. M. Bashari, A. Eibaid and J. Wan, "Influence of low ultrasound intensity on the degradation of dextran catalyzed by dextranase," Ultrasonics Sonochemistry, vol. 20, p. 155-161, 2013.

[6]. N.L. Le and V.V.M. Le, "Application of ultrasound in grape mash treatment in juice processing," Ultrasonics Sonochemistry, vol. 17, no. 1, p. 273-279, 2010.

[7]. T.T.T. Tran and V.V.M. Le, "Effect of Ultrasonic Treatment on The Amylase Activity of Dextrozyme GA Preparation," Journal of science and technology, vol. 52, no. 5B, pp. 466-471, 2014.

[8]. P. Bernfeld, "Amylases $\alpha$ and $\beta$, " in Method in Enzymology, New York, Academic Press, 1955, pp. 149-158.

[9]. A.Bowden, Fundamentals of Enzyme Kinetics, Wiley-Blackwell, 2012, p. 510. 